\title{
Catharanthus roseus (Apocynaceae) naturally infected with diverse phytoplasmas in Costa Rica
}

\author{
William Villalobos ${ }^{1}$, Kristi Bottner-Parker ${ }^{2}$, Ing-Ming Lee ${ }^{2}$, Mauricio Montero-Astúa ${ }^{1,3}$, \\ Federico J. Albertazzi ${ }^{1,4}$, Teresita Coto-Morales ${ }^{1}$, Izayana Sandoval-Carvajal ${ }^{1}$, \\ Laura Garita $^{1}$ \& Lisela Moreira ${ }^{1,3}$ \\ 1. Centro de Investigación en Biología Celular y Molecular (CIBCM), Universidad de Costa Rica (UCR), San José \\ 11501-2060, Costa Rica; william.villalobos@ucr.ac.cr, teresita.coto@ucr.ac.cr, izayana.sandoval@ucr.ac.cr, \\ laura.garita@ucr.ac.cr \\ 2. Molecular Plant Pathology Laboratory, USDA-Agricultural Research Service, Beltsville, MD 20705, USA; \\ kristi.bottner@ars.usda.gov, ingming.lee@ars.usda.gov \\ 3. Escuela de Agronomía, UCR, San José 11501-2060, Costa Rica; mauricio.monteroastua@ucr.ac.cr, \\ lisela.moreira@ucr.ac.cr \\ 4. Escuela de Biología, UCR, San José 11501-2060, Costa Rica; federico.albertazzi@ucr.ac.cr
}

Received 08-VIII-2018. C Corrected 03-X-2018. Accepted 10-XII-2018.

\begin{abstract}
Phytoplasmas (class Mollicutes) are causal agents of plant diseases with an economic impact on crops or threatening local biodiversity. A survey was conducted from 2012 to 2016 on infected Catharanthus roseus plants that exhibited symptoms reminiscent of phytoplasma infection throughout Costa Rica. A total of 73 plants were collected exhibiting symptoms such as virescence, phyllody, axillary proliferation, little leaf, leaf malformation, chlorosis, or yellowing. All samples were tested by nested PCR using phytoplasma universal and specific primer pairs. Phytoplasma infection was detected in $52(71.2 \%)$ of the plants collected. Phytoplasmas of six subgroups belonging to $16 \mathrm{Sr}$ groups I, III, IX, XIII and XV were identified based on sequencing and in silico RFLP analyses. 'Candidatus Phytoplasma asteris' (16SrI) was the predominant group among the positive samples $(\mathrm{n}=30)$ showing variety of symptoms and wide distribution from sea level to $c a .1400$ m.a.s.l. in six of the seven Costa Rican provinces. Group 16SrIII was the second most abundant (14 samples); and the remaining three groups were seldom found in C. roseus (8 samples). Moreover, group 16SrXIII phytoplasma was detected for the first time in the country. To the best of our knowledge, this is the first report of natural infection of $C$. roseus with phytoplasma subgroups 16SrI-B, 16SrI-P, 16SrIII-F, 16SrIX-F, 16SrXIII-A, and 16SrXV-B in Costa Rica and Central America.
\end{abstract}

Key words: periwinkle; nested PCR; 16SrI; 16SrIII; 16SrIX; 16SrXIII; 16SrXV.

Villalobos, W., Bottner-Parker, K., Lee, I. M., Montero-Astúa, M., Albertazzi, F. J., CotoMorales, T., Sandoval-Carvajal, I., Garita, L., \& Moreira, L. (2019). Catharanthus roseus (Apocynaceae) naturally infected with diverse phytoplasmas in Costa Rica. Revista de Biología Tropical, 67(1), 321-336.

Phytoplasmas, previously termed mycoplasma-like organisms, are small, cell wallless, phloem-limited prokaryotes that have been reported to be associated with diseases in several hundred to more than 1000 plant species worldwide (Lee, Davis, \& Gundersen-Rindal,
2000; Hogenhout, et al., 2008). They were first discovered, through electron microscopy studies, by a group of Japanese scientists in 1967 (Doi, Teranaka, Yora, \& Asuyama, 1967). Based on phylogenetic analyses using 16S rRNA and/or ribosomal protein gene 
sequences, phytoplasmas have been placed in the class Mollicutes (Gundersen, Lee, Rehner, Davis, \& Kingsbury, 1994). Phytoplasma infection interferes with plant development and induces morphological and physiological changes, including: witches'-broom, phyllody, virescence, bolting, reddening of leaves and stems, generalized yellowing, stunting and decline (Hogenhout et al., 2008). These mollicutes are responsible for devastating damage to many economically important crops, fruit trees, woody trees and ornamental plants worldwide. Some of these diseases can cause death of the plant host resulting in serious economic impact and may affect local biodiversity (Maejima, Kenro Oshima, \& Namda, 2014; Marcone, 2014).

In nature, phytoplasmas live and reproduce in the phloem tissue of plants, as well as in the salivary glands and other tissues of some phloem feeding Hemiptera of the families Cicadellidae, Cixiidae, Delphacidae, Derbidae, Flatidae and Psyllidae. Phytoplasmal diseases are transmitted from plant to plant by one of such insect vectors, as well as by grafting and Cuscuta spp. A suitable combination of various plant hosts and insect vector-mediated transmission are responsible for the horizontal transmission of phytoplasmas between plants (Weintraub \& Beanland, 2006). Some studies suggest the possibility of transovarial transmission of phytoplasmas (Alma et al., 1997; Hanboonsong, Choosai, Panyim, \& Damak, 2002; Mittelberger et al., 2017).

Phytoplasmas are difficult to cultivate in vitro, and are therefore poorly characterized bacteria. Molecular methods using the highly conserved 16S rRNA gene as well as other conserved biomarkers, including ribosomal protein, tuf, sec $\mathrm{A}$, and $\sec \mathrm{Y}$ genes, have been used for the detection, differentiation, and classification of phytoplasmas (Lee, Gundersen-Rindal, Davis, \& Batoszyk, 1998b; Seemüller, Marcone, Lauer, Ragozzino, \& Göschl, 1998; Marcone, Lee, Davis, Ragozzino, \& Seemüller, 2000; Hodgetts, Boonham, Mumford, Harrison, \& Dickinson, 2008). Based on molecular classification and the guidelines established by the IRPCM Phytoplasma/Spiroplasma Working Team-Phytoplasma Taxonomy Group (IRPCM, 2004), phytoplasmas have been classified into 43 'Candidatus Phytoplasma' species (Arneodo, et al., 2007; Fernández, Galdeano, Kornowski, Arneado, \& Conci, 2016; Zhao \& Davis, 2016; Miyazaki et al., 2017; Naderali et al., 2017).

Phytoplasma infection with one of four $16 \mathrm{Sr}$ groups (16SrI, 16SrIII, 16SrIX, and $16 \mathrm{Sr}$ $\mathrm{XV})$ has been reported in various plant species in Costa Rica (Gámez \& León, 1985; Kenyon, Harrison, \& Richardson, 1999; Villalobos, Moreira, Bottner, Lee, \& Rivera, 2002; Villalobos et al., 2011; Pardo, Truke, Cardozo, Varela, \& Alvarez, 2014). Although natural phytoplasma infection in Catharanthus roseus G. Don (Apocynaceae) has been reported elsewhere (Pérez-López, Olivier, Luna-Rodríguez, Adame-García, \& Dumonceaux, 2016b), to our knowledge, it has not been reported in Costa Rica. This plant species, a perennial herbaceous plant native to Madagascar, is commonly known as Madagascar periwinkle, vinca, or "mariposa" (butterfly) in Costa Rica. It is widely cultivated as a popular ornamental plant and can be found in gardens and homes across the warmer parts of tropical and subtropical countries. Periwinkle plants are used as an experimental host for the maintenance of phytoplasma strains, as well as to study phytoplasma-host interactions (Nejat et al., 2013; 2015).

We consistently found Madagascar periwinkle plants exhibiting symptoms reminiscent of phytoplasma infection (Hogenhout et al., 2008) in gardens, parks, living-fences and along sidewalks throughout Costa Rica. In this study, we examined a sample of 73 symptomatic C. roseus plants collected from 2012 to 2016. The phytoplasmas were detected and identified by nested PCR, sequencing, in silico RFLP and phylogenetic analyses. This work reports natural infection of Madagascar periwinkle plants with different phytoplasma $16 \mathrm{Sr}$ subgroups in Costa Rica. 


\section{MATERIALS AND METHODS}

Sampling: A total of 73 C. roseus plants exhibiting different symptoms related to phytoplasma infection (witches'-broom, phyllody, virescense, leaf yellowing, dwarfing, etc.) were collected from home gardens, sidewalks, and parks at different locations in the seven provinces of Costa Rica [Alajuela province: Alajuela, Cartago province: Dulce Nombre, Paraíso, Turrialba; Guanacaste province: Hojancha, Filadelfia, Cañas, Sámara, Santa Cruz; Heredia province: Santo Domingo; Limón province: Cahuita; Puntarenas province: Chomes, Esparza, Paso Canoas, Potrero Grande, Quebrada Grande, Tárcoles; and San José province: Coronado, Moravia, Pérez Zeledón, San Pedro, Sabanilla]. Two Gliricidia sepium trees showing little leaf disease (GLLD) were collected in La Guácima (Alajuela province) to compare sequences with those from $C$. roseus samples harboring group 16SrIX phytoplasmas.

DNA extraction and amplification: Leaf midribs and petiole $(100 \mathrm{mg})$ from each sample of $C$. roseus and G. sepium were extracted using the DNeasy Plant Mini Kit (Qiagen, Hilden, Germany) according to the manufacturer's instruction. Additionally, DNA from healthy periwinkle plants grown in an insectproof greenhouse was extracted as negative control. DNA extracted from Sechium edule infected with 16SrI-B phytoplasma (Villalobos et al., 2002) was used as a positive control.

Detection of phytoplasmas was carried out by amplification of 16S rDNA in a nested polymerase chain reaction (PCR) assay, using universal primer pair P1/P7 (Deng \& Hiruki, 1991; Smart, et al., 1996) in the first reaction followed by R16F2n/R16R2 (Gundersen, Lee, Rehner, Davis, \& Kingsbury, 1994; Lee, Gundersen, Hammond, \& Davis, 1994) in the second reaction. Amplifications were performed with a PCR Gradient Palm Cycler (Corbett Research Model CG1-96, Australia) in $27 \mu \mathrm{l}$ reactions containing $200 \mu \mathrm{M}$ of each of the four dNTPs, $0.4 \mu \mathrm{M}$ of each primer, $1.5 \mathrm{mM} \mathrm{MgCl}_{2}, 0.625$ units of DreamTaq
DNA polymerase (Thermo Fisher Scientific Inc. USA), and $2 \mu$ l of DNA extracted. Diluted PCR product (1:20) with UltraPure DNase/ RNase free distilled water (Thermo Fisher Scientific Inc.) from the first amplification was used as template in the nested PCR. The PCR thermocycler profile for both amplification steps was denaturation at $94{ }^{\circ} \mathrm{C}$ for $1 \mathrm{~min}(2$ min for the first cycle), annealing at $55^{\circ} \mathrm{C}$ for $1 \mathrm{~min}$, and extension at $72{ }^{\circ} \mathrm{C}$ for $2 \mathrm{~min}(10 \mathrm{~min}$ for the last cycle). The amplified products $(5 \mu \mathrm{l}$ of each PCR reaction) were evaluated by electrophoresis through $1 \%$ agarose gels, stained with GelRed ${ }^{\mathrm{TM}}$ (Biotium, California, USA) and visualized with a UV transilluminator.

\section{Sequencing and phylogenetic analyses:} All samples $(\mathrm{n}=52)$ that yielded amplicons of about $1.2 \mathrm{~Kb}$ in the previous nested PCR were used to prepare new reactions using only the internal primer pairs of the nested PCR protocol (Gundersen \& Lee, 1996a) and were directly sequenced in both directions by Macrogen Inc. (Korea). A contig sequence using the forward and reverse sequences was obtained for each sample using BioEdit software v. 7.2.5 (Hall, 1999). Confirmation of phytoplasmas infection and preliminary identification of the phytoplasma group for each sample was done using BLAST algorithm (http://blast.ncbi.nlm. nih.gov/Blast.cgi).

A total of five phytoplasma groups were identified within those 52 positive samples (Digital Appendix 1). Four representative samples for group 16SrI (the most abundant) and one each from the other four phytoplasma groups (16SrIII, 16SrIX, 16SrXIII and $16 \mathrm{SrXV}$ ) were selected for further analyses. Additionally, two samples of G. sepium were included as control for phytoplasma group 16SrIX. A semi-nested PCR assay was performed using primer pair P1/16S-SR in the first reaction followed by P1A/16S-SR (Lee, et al., 2004) in the second reaction to amplify the near full length 16S rRNA gene (about 1.5 $\mathrm{Kb}$ ). The nested PCR products (a total of eight) were purified using PCR Kleen Spin Columns (Bio-Rad, Hercules, CA) and cloned into 
Escherichia coli (TOP10) by using the TOPO TA Cloning Kit (Invitrogen, Carlsbad, CA) according to the manufacturers' instructions. Two clones per sample were sequenced with an automated DNA sequencer (Macrogen Inc., Rockville, MD USA). Sequencing reads were assembled using the SeqMan program from the DNAStar LaserGene software package (DNAStar, Madison, WI) and a final sequence was obtained for each clone. The $i$ PhyClassifier tool (Zhao, et al., 2009) was then used to generate in silico RFLP profiles and determine phytoplasma group classifications. A BLAST search (BLASTn) was utilized to find similar sequences deposited in GenBank. Sequences from clones obtained from $C$. roseus have been deposited to GenBank under accession numbers MH428957 to MH428964. Additionally, sequences of Costa Rican GLLD are available as MH428965 and MH428966.

The sequences of subgroup representatives obtained in this study as well as 30 phytoplasma strains available from GenBank, and Acholeplasma palmae J233 (as outgroup) were aligned using ClustalW (Thompson, Higgins, \& Gibson, 1994) in MEGA v. 7.0 (Kumar, Stecher, $\&$ Tamura, 2016). The final alignment included a total of 1401 positions. The phylogenetic analysis was inferred with MEGA7 using the Maximum Likelihood method based on the General Time Reversible model and the rate of variation per site was determined by a gamma distribution with a proportion of invariable sites $(\mathrm{G}+\mathrm{I})$. The estimation of stability and support for the inferred clades were performed using bootstrap analyses of 2500 replicates.

\section{RESULTS}

A total of 73 C. roseus samples were collected in different regions of the country and phytoplasma infection was detected in $71.2 \%$ (52/73) by nested PCR. Ten different symptom combinations (Table 1) were observed in the phytoplasma-positive C. roseus plants (Fig. 1A, Fig. 1B, Fig. 1C, Fig. 1D, Fig. 1E and Fig. 1F). The most common symptom was virescence (19 plants) or virescence combined with other symptoms (11 plants), representing in total $57.7 \%$ of the positive plants. The second most abundant symptom was yellowing, observed on 19 plants (36.5\%). We were not able to find a pattern/association between type of symptoms and other variables, including phytoplasma group or geographic altitude where the plant was collected. Nonetheless,

TABLE 1

Number of samples in each symptom category associated with each of five phytoplasma $16 \mathrm{Sr}$ groups identified in Catharanthus roseus collected in Costa Rica from 2012-2016

\section{CUADRO 1}

Número de muestras según síntoma observado en Catharanthus roseus infectados con fitoplasmas, recolectadas en Costa Rica, 2012-2016

\begin{tabular}{|c|c|c|c|c|c|c|}
\hline \multirow{2}{*}{ Symptoms / Síntomas } & \multicolumn{5}{|c|}{ Phytoplasma group/ Grupo de fitoplasma } & \multirow{2}{*}{ Total } \\
\hline & $16 \mathrm{SrI}$ & $16 \mathrm{SrIII}$ & 16SrIX & 16SrXIII & $16 \mathrm{SrXV}$ & \\
\hline Bolting & 1 & - & - & - & - & 1 \\
\hline Phyllody + little leaf + proliferation & 2 & - & - & - & - & 2 \\
\hline Virescence & 14 & 2 & 1 & 1 & 1 & 19 \\
\hline Virescence + big bud & - & - & - & - & 1 & 1 \\
\hline Virescence + phyllody & 1 & - & - & - & 1 & 2 \\
\hline Virescence + proliferation & 1 & - & - & - & - & 1 \\
\hline Virescence + proliferation + little leaf & 2 & - & - & 1 & - & 3 \\
\hline Virescence + little leaf + stunting + short internodes & - & 3 & - & - & - & 3 \\
\hline Virescence + yellowing & 1 & - & - & - & - & 1 \\
\hline Yellowing & 8 & 9 & 2 & - & - & 19 \\
\hline
\end{tabular}



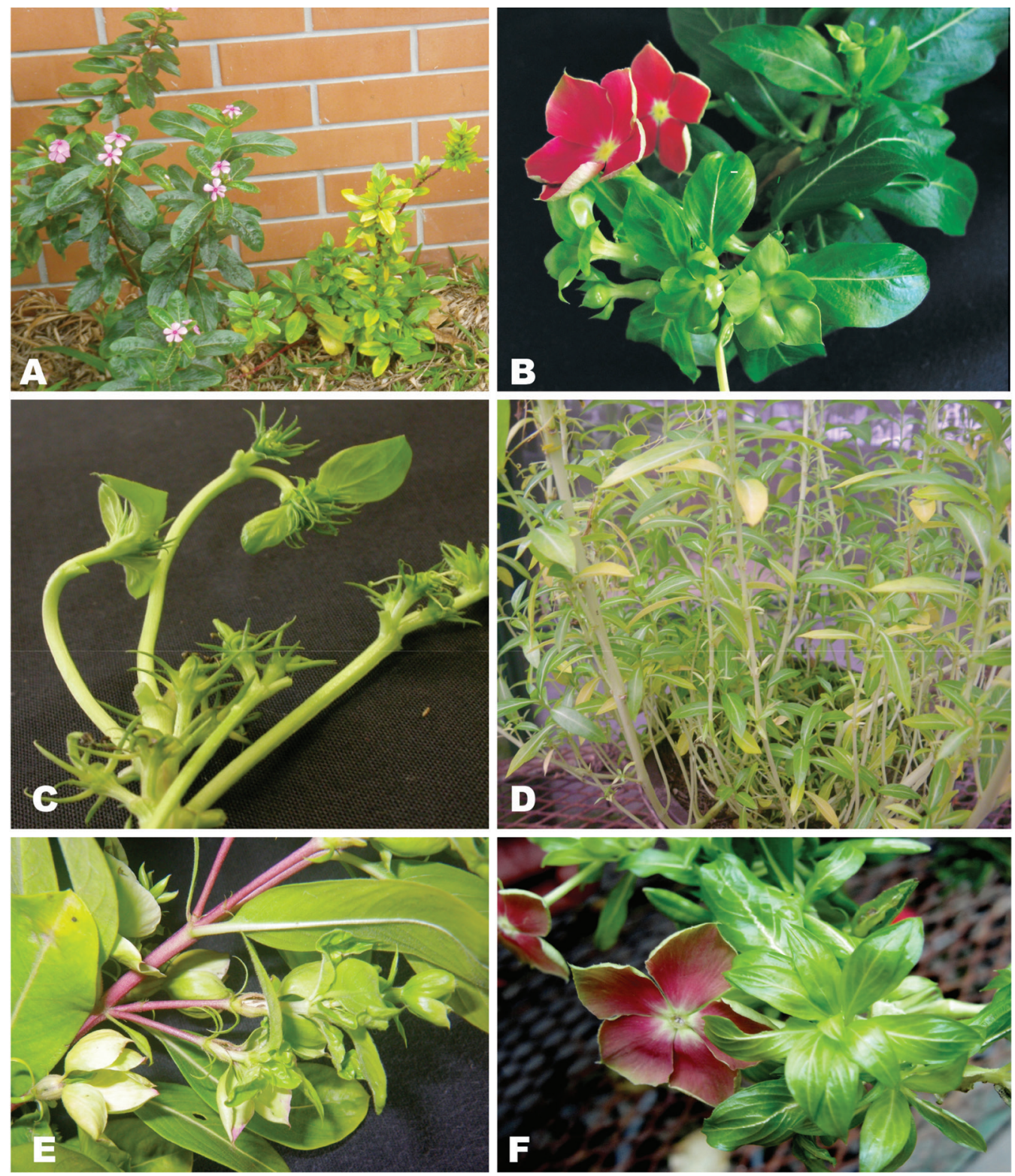

Fig. 1. Symptoms exhibited by periwinkle plants infected with phytoplasmas including A) yellowing, dwarfing, little leaf and axilar proliferation, B) virescence, C) floral abortion and malformation, D) stalk elongation (bolting), E) big bud, F) phyllody.

Fig. 1. Síntomas presentados por plantas de vinca infectadas con fitoplasmas incluyeron A) amarillamiento, enanismo, hoja pequeña y brotación múltiple axilar, B) enverdecimiento floral, C) aborto y deformación floral, D) tallos elongados, E) base floral engrosada, F) filodia.

perhaps due to a greater number of samples, the 16SrI group showed variation regarding symptom expression in the plant host $C$. roseus.

According to BLAST search results, phytoplasmas belonging to groups: 16SrI, $16 \mathrm{SrIII}$,
16SrIX, 16SrXIII and 16SrXV were detected in $30,14,3,2$ and 3 symptomatic $C$. roseus samples (Table 2), respectively. No mixed infections were found, despite the presence of two or three different phytoplasmas in some 
TABLE 2

Number of infected Catharanthus roseus samples associated with each of five phytoplasma 16Sr groups identified and province of collection in Costa Rica

CUADRO 2

Número de muestras de Catharanthus roseus según grupo de fitoplasma detectado por provincia de recolección en Costa Rica

\begin{tabular}{|c|c|c|c|c|c|c|}
\hline \multirow{2}{*}{ Province / Provincia } & \multicolumn{5}{|c|}{ Phytoplasma group / Grupo de fitoplasma } & \multirow{2}{*}{ Total } \\
\hline & $16 \mathrm{SrI}$ & 16SrIII & 16SrIX & 16SrXIII & $16 \mathrm{SrXV}$ & \\
\hline Cartago & 7 & 1 & - & 1 & - & 9 \\
\hline Guanacaste & 6 & - & - & 1 & 3 & 10 \\
\hline Heredia & 1 & 1 & - & - & - & 2 \\
\hline Limón & 1 & - & - & - & - & 1 \\
\hline Puntarenas & 4 & - & 1 & - & - & 5 \\
\hline San José & 11 & 12 & 2 & - & - & 25 \\
\hline Total & 30 & 14 & 3 & 2 & 3 & 52 \\
\hline
\end{tabular}

locations in the same province (Table 2). The altitudinal distribution of phytoplasmas suggested that $16 \mathrm{SrI}$ group has a wide distribution, while groups 16SrIII and 16SrXV showed presence above 1200 masl or below 500 masl, respectively (Fig. 2).

The majority of nucleotide sequences obtained from positive plants ( 30 of 52 sequences) indicated infection with ' $\mathrm{Ca}$. Phytoplasma asteris', with similarities between 98-99 \% with subgroup 16SrI-B representatives. Plants infected with this subgroup

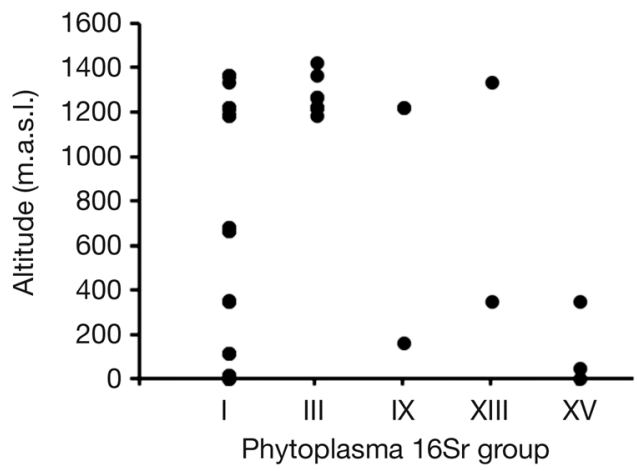

Fig. 2. Altitudinal distribution (meters above sea level, m.a.s.1.) of Catharantus roseus samples per phytoplasma group collected in this study in Costa Rica.

Fig. 2. Distribución altitudinal (metros sobre el nivel del mar, m.s.n.m.) de muestras de Catharantus roseus según grupo de fitoplasmas detectado en este estudio realizado en Costa Rica. were found in six out of seven provinces in the country (Table 2). Only one infected $C$. roseus (CR02) expressing bolting symptoms (GenBank accession no. MH428961), detected in Turrialba city (Cartago province), showed $97 \%$ similarity to subgroup $16 \mathrm{SrI}-\mathrm{P}$ (GenBank accession no. AF503568).

A summary of data obtained using the $i$ PhyClassifier tool to analyze cloned phytoplasma 16S rRNA gene sequences obtained in this study is presented in Table 3 . The virtual RFLPs patterns of three sequences representative of subgroup 16SrI-B (GenBank accession nos. MH428957, MH428960 and MH428964) were identical to the reference strain of this subgroup. However, the sequence of a sample from Turrialba identified as subgroup 16SrI-P (GenBank accession no. MH428961) showed identical virtual RFLP patterns to this subgroup with 16 out of 17 enzymes used, but the pattern resolved using HhaI was like other strains in the 16SrI group although dissimilar to subgroup 16SrI-P (Fig. 3A), suggesting a possible new subgroup within the ' $\mathrm{Ca}$. Phytoplasma asteris' group in Costa Rica.

The second group in importance, by number of detections, was group 16SrIII (X-disease group or ' $C a$. Phytoplasma pruni'). Eleven samples collected from gardens in three different provinces (Heredia, Cartago and San José) were infected with group 16SrIII phytoplasma 


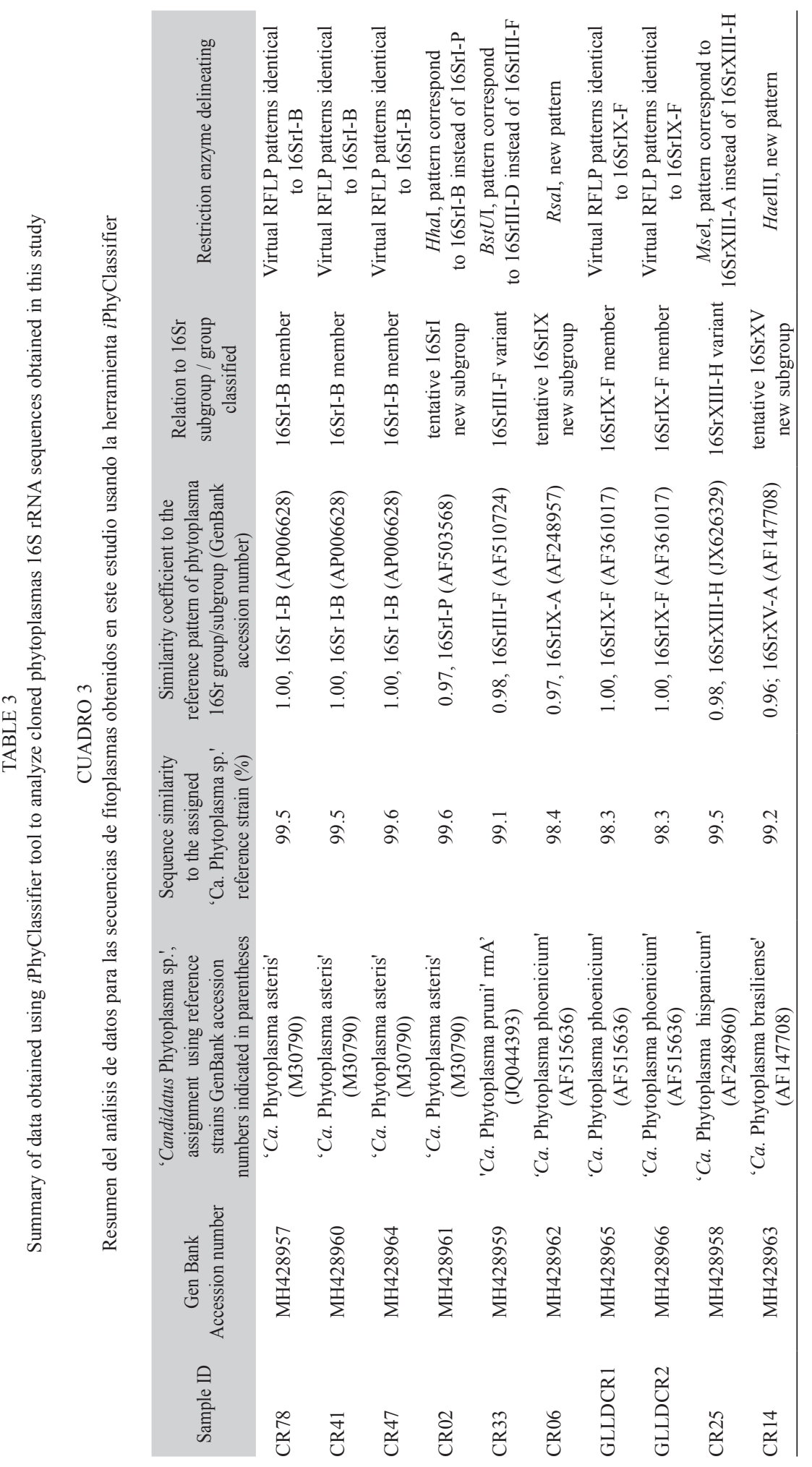




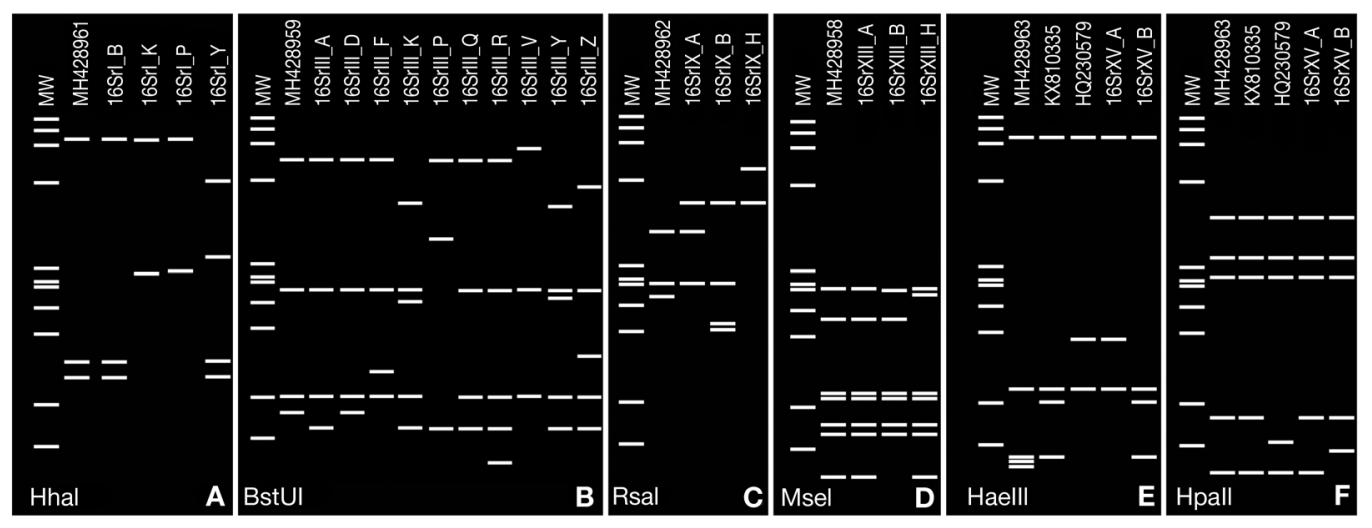

Fig. 3. Computer-simulated virtual RFLP patterns generated from in silico digestions of phytoplasma 16S rRNA genes from strains detected in this study belonging to groups: (A) 16SrI using HhaI (MH428961: 16SrI-P*); (B) 16SrIII using

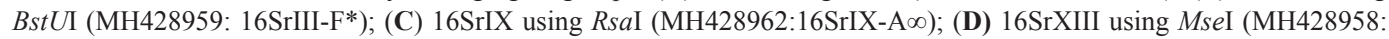
16SrXIII-H*); (E, F) 16SrXV using HaeIII and HpaII (MH428963: 16SrXV-A $\infty$ ), obtained using iPhyClassifier tool. GenBank accession numbers are shown in parenthesis after each subgroup. Phytoplasma subgroup variant are indicated by an asterisk and tentative new subgroup by $\infty$ symbol after subgroup number. GenBank acc.nos. KX810335 and HQ230579 in $\mathbf{E}$ and $\mathbf{F}$ correspond to other variants to subgroups $16 \mathrm{SrXV}-\mathrm{A}$ and $16 \mathrm{SrXV}-\mathrm{B}$ reported previously. Lanes MW, HaeIII digest of $\Phi$ X174 RFI DNA; fragment sizes (bp) from top to bottom: 1353, 1078, 872, 603, 310, 281, 271, 234, 194, 118, 72. Figure edited with Paint.net software.

Fig. 3. Patrones RFLPs virtuales para los fitoplasmas detectados en el estudio respecto a los patrones mostrados en el grupo asignado: (A) 16SrI usando HhaI (MH428961: 16SrI-P*); (B) 16SrIII con BstUI (MH428959: 16SrIII-F*); (C) 16SrIX usando RsaI (MH428962:16SrIX-Aœ); (D) 16SrXIII usando MseI (MH428958: 16SrXIII-H*); (E, F) 16SrXV con HaeIII y HpaII (MH428963: 16SrXV-Aœ), obtenidos con el programa iPhyClassifier. Los números de registro del GenBank para cada subgrupo se muestran en paréntesis. Los variantes de subgrupos se indican con un asterisco mientras que los potenciales nuevos subgrupos con el símbolo $\infty$. Los números de registro GenBank: KX810335 y HQ230579 en E y F corresponden a otras variantes en $16 \mathrm{SrXV}$ reportadas. Los carriles del marcador de peso molecular (MW) corresponden a fragmentos de ADN del bacteriófago $\Phi$ X174 RFI digerido con HaeIII, el tamaño de los fragmentos de arriba hacia abajo es: 1353, 1078, 872, 603, 310, 281, 271, 234, 194, 118, 72 pares de bases. Figura editada con Paint.net.

strains. The search for similar sequences in public databases showed $99 \%$ identity to Mexican Xalapa periwinkle virescence phytoplasma (GenBank accession no. KY778009). The virtual RFLP pattern derived from one of our samples (GenBank accession no. MH428959) was most similar to the reference pattern of the 16SrIII-F subgroup (GenBank accession no. AF510724), with a similarity coefficient of 0.98. However, the MH428959 phytoplasma is a variant of subgroup $16 \mathrm{SrIII}-\mathrm{F}$, because the virtual RFLP pattern resolved by BstUI corresponded to subgroup 16SrIII-D instead of 16SrIII-F (Fig. 3B).

The presence of three other groups: 16SrIX ('Ca. Phytoplasma phoenicium'), 16Sr-XIII ('Ca. Phytoplasma hispanicum') and $16 \mathrm{Sr}-\mathrm{XV}$ ('Ca. Phytoplasma brasiliense') was detected in a limited number of samples. Only eight plants in total from three provinces (Cartago, Guanacaste, and San José) carried one of these groups. Three $C$. roseus samples infected with 16SrIX group phytoplasmas were detected. A sample collected in Potrero Grande (Puntarenas), GenBank accession no. MH428962, showed $99 \%$ similarity to pigeon pea witches'broom (GenBank accession no. KJ817866), Crotalaria juncea witches'-broom (GenBank accession no. KF941131), and other phytoplasmal strains belonging to that group. Results from the $i$ Phyclassifier tool for this sample classified it (similarity coefficient $=0.97$ ) as belonging to subgroup 16SrIX-A (PPWB, GenBank accession: AF248957). However, the virtual RFLPs obtained for this sample displayed a unique RFLP pattern of three bands with 
enzyme RsaI (Fig. 3C). When this sample was compared to sequences obtained in Costa Rica during this research from GLLD, GenBank accession nos. MH428965 and MH428966, results showed that the phytoplasmas from group 16SrIX detected in periwinkle and Gliricidia in Costa Rica are different from each other, and the strain found in periwinkle may represent a variant of subgroup 16SrIX-A, meanwhile Costa Rican GLLD strains have $100 \%$ identity to those from Honduran GLLD.

The presence of group 16SrXIII, ' $\mathrm{Ca}$. Phytoplasma hispanicum', in Costa Rica was first detected in this survey. Two plants showing virescence and harboring this phytoplasma group were collected in Dulce Nombre (Cartago) and Hojancha (Guanacaste, GenBank accession no. MH428958). The 16S rRNA gene sequences obtained and compared by the BLAST algorithm showed $99 \%$ identity with Mexican periwinkle virescence phytoplasma (MPVP, GenBank accession no. AF248960). According to virtual RFLP analysis, it was most similar to the reference pattern of subgroup 16SrXIII-H (GenBank accession no. JX626329), with a similarity coefficient of 0.98 , suggesting this may be a variant of 16SrXIII-H. The virtual RFLPs displayed patterns like those of subgroup 16SrXIII-H, except for a unique pattern for enzyme MseI (Fig. 3D).

The fifth phytoplasmas group detected during this work was ' $\mathrm{Ca}$. Phytoplasma brasiliense' (16SrXV). Infection of $C$. roseus by this group was confined to Guanacaste province. All three plants harboring group 16SrXV showed virescence; with one plant (CR03) collected in Samara (Guanacaste) also exhibiting phyllody and another one (CR14, Santa Cruz, Guanacaste) also exhibiting big bud (Fig. 1E). The 16S rRNA gene sequences obtained showed $99 \%$ similarity with sequences corresponding to this phytoplasma infecting Vitis vinifera, Carica papaya, Crotalaria juncea, Hibiscus sp. and Guazuma ulmifolia from Peru (GenBank accession nos. KX6708079, KX810334-6), Brazil (GenBank accession nos. KF878382 and AF147708), and Costa Rica (GenBank accession nos. HQ258882-3), respectively. However, an in silico RFLP comparison using the $i$ PhyClassifier showed that the phytoplasma found in $C$. roseus is not the same as the 16SrXV-B subgroup previously reported in Costa Rica infecting G. ulmifolia. According to the virtual RFLP pattern obtained for the sequence of GenBank accession no. MH428963, the most similar to it was the reference pattern of subgroup 16SrXV-A (GenBank accession no. AF147708), with a similarity coefficient of 0.96 , suggesting this strain may represent a tentative new $16 \mathrm{SrXV}$ subgroup. The virtual RFLP analysis displayed a unique and different RFLP pattern with HaeIII to previously reported strains (Fig. 3E). The 16 remaining virtual RFLPs showed exactly the same patterns to those of subgroup 16SrXV-A, for example with enzyme HpaII (Fig. 3F).

Phylogenetic analysis comparison based on 16S rDNA sequences of phytoplasma subgroups found in this study showed $16 \mathrm{Sr}$ group clustering consistent with the group identification by BLAST analysis. The same consistent phylogenetic clustering was found with representatives of groups 16SrIII, 16SrIX and 16SrXIII. However, representatives of subgroups 16SrI-B and 16SrI-P, obtained in this study, clustered together instead of with related sequences obtained from GenBank, suggesting a possible relationship due to geographic origin. Also, contrary to the $i$ PhyClassifier results, the representative strain of group $16 \mathrm{SrXV}$ from C. roseus, obtained in this study, clustered more closely to subgroup 16SrXV-B strains than subgroup 16SrXV-A (Fig. 4).

\section{DISCUSSION}

In this study, phytoplasmas were detected in naturally infected $C$. roseus, in six of seven provinces in Costa Rica (excluding Alajuela), 16SrRNA gene sequences indicated that they belonged to five groups: 16SrI, 16SrIII, 16SrIX, $16 \mathrm{SrXV}$, and $16 \mathrm{SrXIII}$. The first four groups were previously identified in other plant hosts in Costa Rica (Kenyon et al., 1999; Villalobos et al., 2002; 2011; Pardo et al., 2014). Group 16 SrXIII was detected in the country for the 


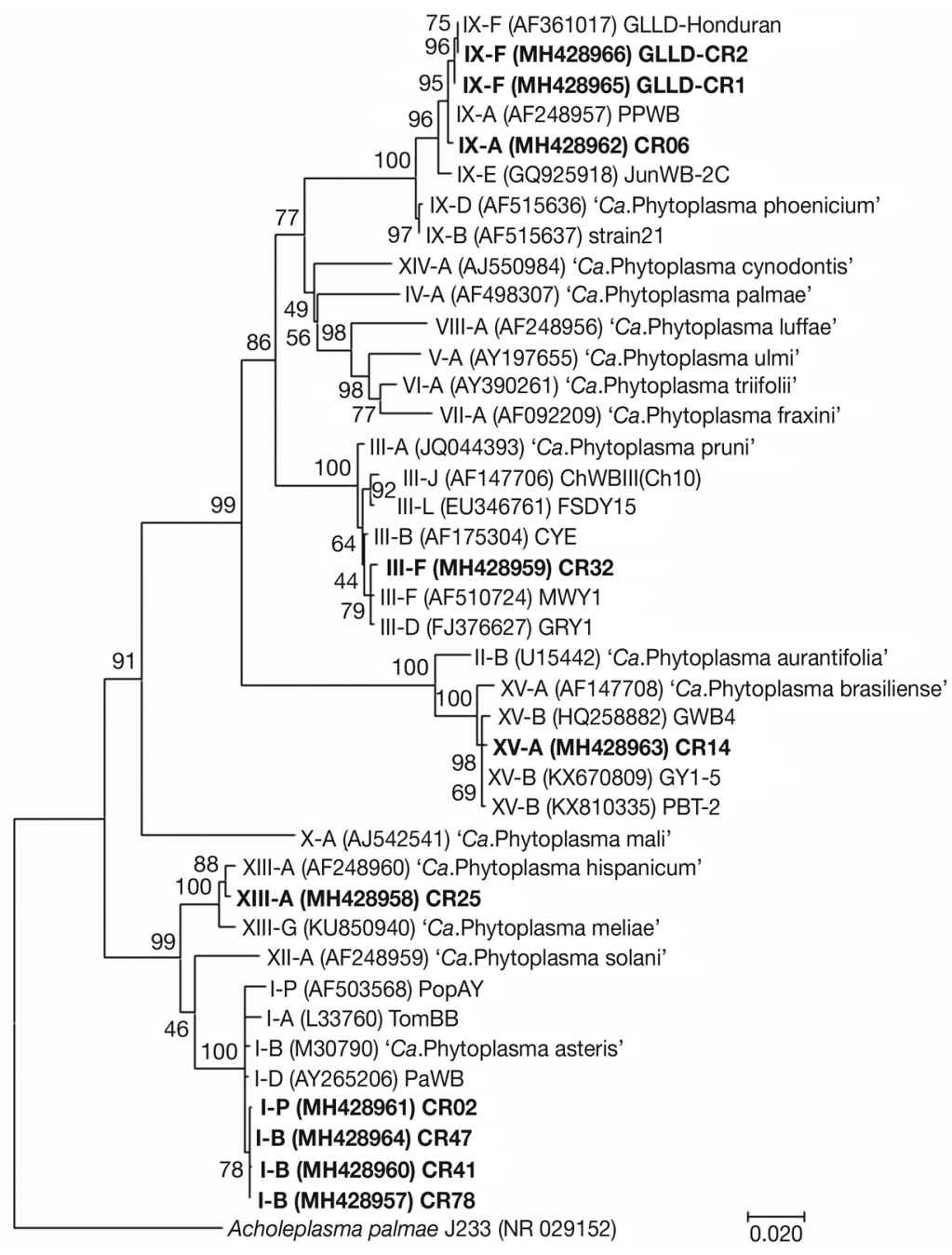

Fig. 4. Phylogenetic tree inferred from analysis of $16 \mathrm{~S}$ rRNA gene sequences by Maximum Likelihood method based on the General Time Reversible model. A bootstrap test with 2500 replicates was done to support reliability of the analysis. The analysis involved 41 nucleotide sequences, included reference strains of 30 previously described $\mathrm{Ca}$. Phytoplasma species and subgroup strains obtained from GenBank and Acholeplasma palmae J233 (NR_029152), as outgroup to root the phylogenetic tree. GenBank accession numbers of all sequences are showed in parenthesis and sequences obtained in this study are indicated in bold font. Bar $=0.02$ nucleotide substitutions per site.

Fig. 4. Árbol filogenético inferido del análisis de las secuencias del gen 16S rRNA por el método de Máxima Verosimilitud empleando el modelo "General Time Reversible", empleando 2500 iteraciones para respaldar la confiabilidad del análisis. El análisis incluyó 41 secuencias nucleotídicas, entre ellas 30 de Ca. Phytoplasma spp. y de los subgrupos de referencia previamente descritas, disponibles en el GenBank, además del aislamiento J233 de Acholeplasma palmae (NR_029152), como grupo externo, empleado para enraizar el árbol filogenético. Los números de registro en el GenBank para las secuencias empleadas se muestran en paréntesis y las obtenidas en este estudio se resaltan en negrita. Bar $=0.02$ sustituciones nucleotídicas por sitio.

first time. Moreover, three new tentative subgroups into $16 \mathrm{SrI}, 16 \mathrm{SrIX}$ and $16 \mathrm{SrXV}$ groups were also described. These findings suggested that the phytoplasmas present in Costa Rica are more diverse and complex than previously known, and these rise potential risk of phytoplasmal diseases to economically crops as well as wild biodiversity. Despite the presence of 
two different phytoplasmas in some locations in the same province (Table 2), no mixed infections were found in this study probably because few clones per plant were analyzed.

Catharanthus roseus has been reported as a natural host for phytoplasmas groups 16SrI, 16SrIII, 16SrIX, 16SrXV, 16SrXIII, in North and South America, and the Caribbean islands, but not from the Central American region (Lee et al., 1998b; Lee, Davis, \& Gundersen-Rindall, 2000; Montano, Dally, Davis, Pimentel, \& Brioso, 2001b; Torres, Galdeano, Docampo, \& Conci, 2004; Duduk, Mejia, Calari, \& Bertaccini, 2008; Barbosa, Eckstein, Bergamin Filho, Bedendo, \& Kitajima, 2012; Galdeano, Guzmán, Fernández, \& Conci, 2013; Dumonceaux, Green, Hammond, Pérez, \& Olivier, 2014; Caicedo, Rivera-Vargas, Segarra, \& Davis, 2015; Davis, Harrison, Zhao, Wei, \& Dally, 2016; Pérez-López, LunaRodríguez, Olivier, \& Dumonceaux, 2016a). According to Montano et al. (2001b), C. roseus is a well-known experimental host for phytoplasmas, however few incidences of natural infections have been reported and its role related to natural dissemination and disease spread is uncertain. Nevertheless, considering a different perspective, $C$. roseus may be deployed as a sentinel plant for phytoplasma occurrence in a geographical area, as this study is showing.

Subgroup 16SrI-B phytoplasma strains ('Ca. Phytoplasma asteris') have been detected in Costa Rica associated with diseases affecting crops, landscape trees, and wild shrubs (Gámez \& León, 1985; Villalobos et al., 2002, SaboríoRodríguez, Villalobos, \& Rivera, 2007). Two epidemics associated with this phytoplasma subgroup caused severe economic losses to chayote (Sechium edule) growers during 20012002, and to coffee growers during 2006-2007 due the infection of Erythrina trees, which are used as shade trees for coffee crop production in Costa Rica (Saborío-Rodríguez et al., 2007). In this study, this subgroup was also the most widespread in the country. We hypothesize that $16 \mathrm{SrI}$ group has been present longer in the country; therefore, allowing the emergence of new host-vector interactions, recently three wild plant species belonging to Anacardiaceae (Villalobos, unpublished), Asteraceae / Compositae and Rubiaceae (Villalobos, MonteroAstúa, Coto, Sandoval, \& Moreira, 2018) have been detected as new hosts for this group.

The phytoplasma strain variant of subgroup 16SrI-P found in Turrialba (Cartago province, GenBank accession no. MH428961) has not been previously reported in Costa Rica or Central America. This subgroup was reported by Šeruga et al. (2003) infecting Populus nigra trees in Croatia. However, BLASTn top hit results showed $99 \%$ similarity of the Turrialba's periwinkle sample with other phytoplasmas found in North America, including a periwinkle with virescence collected in Yucatan, Mexico (GenBank accession no. EF050085).

Likewise, the detection of phytoplasmas belonging to the 16SrIII-F subgroup (' $\mathrm{Ca}$. Phytoplasma pruni' related strain) is a new report for Costa Rica. This subgroup was also detected in a different host in Cartago province (Villalobos, unpublished data). Pardo et al. (2014) reported subgroup 16SrIII-L infecting cassava crop associated with frog-skin disease in the country. The 16SrIII group has a large number of subgroups and diversity of host species, as well as a wide geographic distribution (Zhao et al., 2009). For example, subgroup 16 SrIII-J is notable for its presence in several hosts and several countries mainly in South America (Galdeano et al., 2013, Pérez-López et al., 2016a).

It is highlighted that natural infections with 16SrIX-A are reported for the first time in Costa Rica. Its presence in at least two geographically distant sites, Southern area (Potrero Grande, Puntarenas) and Central Valley (San Pedro, San José), may suggest a high probability of being found in other areas. The symptoms in both geographic locations are consistent with those previously reported for the host and subgroup 16SrIX-A, such as virescence and yellowing. Natural infection of this plant species by group 16SrIX-A was reported previously in Colombia (Duduk et al., 2008), 
Brazil (Barbosa et al., 2012) and Puerto Rico (Caicedo et al., 2015).

Reports of phytoplasmas belonging to group 16SrXIII have been concentrated in relatively few hosts and restricted geographic locations inside North and South America, infecting C. roseus, Solanum tuberosum, $C$. papaya, S. lycopersicum, Fragaria sp., Melia azedarach, Turnera ulmifolia, Dimorphandra spp. and Thunbergia erecta (Lee et al., 1998b; Harrison, Boa, \& Carpio, 2003; Arneado et al., 2007; Montano et al., 2011; Melo et al., 2013; 2018; Montano, Bertaccini, Guthelle, Paltrinieri, \& Contaldo, 2015; Fernández et al., 2015; Alves, Souza, Ribeiro, da Silva Xavier, \& Carvalho, 2016). The findings reported in this study, expand the geographical range of ' $\mathrm{Ca}$. Phytoplasma hispanicum' (Davis et al., 2016). In this survey, plants infected with subgroup 16SrXIII-A were collected in Cartago province and Guanacaste, and no other hosts have been detected in the country for this phytoplasma group. Additional analyses must be done to determine if this phytoplasma may represent a new subgroup in accordance with differential virtual RFLP patterns, as mentioned above.

Phytoplasmas of group 16SrXV, ' $\mathrm{Ca}$. Phytoplasma brasiliense', were reported in Brazil infecting Hibiscus spp. (Montano et al., 2001a), and other hosts including C. roseus, Crotalaria juncea Brassica oleracea, and Sida rhombifolia (Montano et al., 2001b; Eckstein, Barboza, Rezende, \& Bedendo, 2011; Bianco, et al., 2014; Canale, \& Bedendo, 2013). It is also present in Costa Rica infecting Guazuma ulmifolia (Villalobos, et al., 2011), and in Peru infecting Vitis vinifera and C. papaya (Wei, et al., 2017). The Costa Rican Guazuma strain was classified as subgroup $16 \mathrm{SrXV}-\mathrm{B}$ and the Peruvian strain was identified as a variant. The vinca samples infected with group $16 \mathrm{SrXV}$ were found in different places in the Nicoya peninsula (Guanacaste), where the presence of Guazuma witches'-broom (GWB) is frequent. Nevertheless, sequences showed $99 \%$ sequence similarity to ' $\mathrm{Ca}$. Phytoplasma brasiliense' representatives of subgroup 16SrXV-B variants from Peru (GenBank accession nos.
KX670807-9, KX810334-6), rather than to the surrounding Guazuma phytoplasma. Symptoms associated to natural infection of $C$. roseus by this phytoplasmas in Brazil (Montano et al., 2001b) were yellowing and witches'broom, while in Costa Rica the main symptom was virescence.

As previously reported by Gundersen et al. (1996b) and Lee et al. (1998a, 2004), genetic variation in some phytoplasma strains appears to be associated with ecological isolation, and distinct phytoplasma strains may result from new epidemiological cycles from an original organism (Lee et al., 1998b). The tentative variants and or tentative subgroups observed in phytoplasmas sequenced in this study may be the result of ecological isolation in the $C$. roseus host. It is worth noting that we observed in this study a case where the host species and/ or the putative insect vector associated with the plant host may represent the ecological differentiator for a phytoplasma strain, rather than geographic relationship. Catharanthus roseus plants with phytoplasma infection were collected from Guanacaste, where Guazuma trees with subgroup $16 \mathrm{SrXV}-\mathrm{B}$ phytoplasma infection are common; nevertheless, contrary to our preliminary hypothesis, the $C$. roseus plant growing in Guanacaste, in the same area where Guazuma symptomatic trees occur, were infected with different phytoplasma strains.

Including the results from this report, phytoplasmas belonging to six groups and nine subgroups have been detected in Costa Rica. Moreover, phytoplasma infection has been detected in more than 17 different plant hosts. These findings suggest more diversity of phytoplasmas in the country than previously suspected. Attention to their incidence and geographic spread is important because we hypothesize that new host encounters are allowing the development of previously uncharacterized host-phytoplasma associations. On the other hand, accidental or intentional introduction of phytoplasmas to a new geographical region must be avoided due to the effects that these pathogens may cause to biodiversity. Examples of this situation increase every year 
in scientific reports about new diseases, new hosts, or new geographic range involving these plant pathogens.

This study extends the knowledge of phytoplasmas subgroups in Costa Rica and the Central American region. Here we report for the first time the detection of natural infection of C. roseus with subgroups 16SrI-B, 16SrI-P, 16SrIII-F, 16SrIX-A, 16SrXIII-A, 16SrXV-A. With the exception of 16SrI-B, all of these subgroups were previously unknown to occur in the Central American region. The findings here reported are not only informative, these identify $C$. roseus as a reservoir and potential inoculum source of phytoplasmas to cultivated crops, wild plants, as well as other ornamental plants. Therefore, this plant species may be considered a sentinel to detect phytoplasmas within surrounding crops and natural ecosystems, as well as their genetic diversity.

Ethical statement: authors declare that they all agree with this publication and made significant contributions; that there is no conflict of interest of any kind; and that we followed all pertinent ethical and legal procedures and requirements. A signed document has been filed in the journal archives.

\section{ACKNOWLEDGMENTS}

To Universidad de Costa Rica by supporting this research (801-A1-801, 801-B3-091 and 801-B7-138).

\section{RESUMEN}

Catharanthus roseus (Apocynaceae) naturalmente infectada con diversos fitoplasmas en Costa Rica. Los fitoplasmas (clase Mollicutes) son agentes causales de enfermedades de plantas que provocan pérdidas económicas o amenazan la biodiversidad local. Una recolecta de plantas de Catharanthus roseus que mostraban síntomas de posible infección con fitoplasmas se realizó en diferentes lugares de Costa Rica desde 2012 a 2016. Un total de 73 plantas fueron recolectadas con síntomas tales como viriscencia, filodia, brotación axilar múltiple, reducción foliar, deformación foliar, clorosis, y amarillamiento. Todas las muestras fueron evaluadas mediante PCR anidado usando los pares de imprimadores universales y específicos para fitoplasmas. Infección por fitoplasmas se detectó en 52 $(71.2 \%)$ de las muestras. Fitoplasmas de seis subgrupos dentro de los grupos 16Sr I, III, IX, XIII y XV fueron identificados basados en secuenciación del ADN y análisis de polimorfismos de restricción (RFLP) in silico. El grupo predominante encontrado en las muestras positivas $(\mathrm{n}=30)$ fue el 16SrI ('Candidatus Phytoplasma asteris'), éste mostró variedad de síntomas y amplia distribución desde el nivel del mar hasta casi los 1400 m.s.n.m. en seis de las siete provincias de Costa Rica. El grupo 16SrIII fue el segundo más abundante (14 muestras); y los restantes tres grupos se encontraron en pocas muestras de $C$. roseus (8 muestras). Además, fitoplasmas del grupo 16SrXIII se detectaron por primera vez en el país. De acuerdo a nuestro conocimiento, este es el primer informe de infección natural de C. roseus con fitoplasmas de los subgrupos $16 \mathrm{SrI}-\mathrm{B}$, 16SrI-P, 16SrIII-F, 16SrIX-F, 16SrXIII-A y 16SrXV-B en Costa Rica y Centroamérica.

Palabras clave: vincas; PCR anidado; 16SrI; 16SrIII; 16SrIX; 16SrXIII; 16SrXV.

\section{REFERENCES}

Alma, A., Bosco, D., Danielli, A., Bertaccini, A., Vibio, M., \& Arzone, A. (1997). Identification of phytoplasmas in eggs, nymphs and adults of Scaphoideus titanus Ball reared on healthy plants. Insect Molecular Biology, 6(2), 115-121.

Alves, M. S., de Souza, A. N., Ribeiro, G. M., da Silva Xavier, A., \& Carvalho, C. M. (2016). A 16SrXIII-E subgroup phytoplasma is associated with Thunbergia erecta yellow leaf in Brazil. Australasian Plant Disease Notes, 11(1), 34.

Arneodo, J. D., Marini, D. C., Galdeano, E., Meneguzzi, N., Bacci, M., Domecq, C., None S. F., \& Conci, L. R. (2007). Diversity and geographical distribution of phytoplasmas infecting china-tree in Argentina. Journal Phytopathology, 155(2), 70-75.

Barbosa, J. C., Eckstein, B., Bergamin Filho, A., Bedendo, I. P., \& Kitajima, E. W. (2012). Molecular characterization of a phytoplasma of group 16SrIX related to 'Ca. Phytoplasma phoenicium' in periwinkle in Brazil. Tropical Plant Pathology, 37(2), 130-135.

Bianco, L. F., Martins, E. C., Toloy, R. S., Coletti, D. A. B., Teixeira, D. C., \& Wulff, N. A. (2014). First report of phytoplasmas groups 16SrI and 16SrXV in Crotalaria juncea in Brazil. Plant Disease, 98(7), 990-990.

Caicedo, J. D., Rivera-Vargas, L. I., Segarra, A. E., \& Davis, R. E. (2015). Detection and molecular characterisation of a group 16SrIX phytoplasma infecting citrus (Citrus sinensis and $C$. limon), coffee (Coffea arabica), periwinkle (Catharanthus roseus), and tabebuia (Tabebuia heterophylla) in Puerto Rico. Australasian Plant Disease Notes, 10(1), 1-8. 
Canale, M. C., \& Bedendo, I. P. (2013). 'Candidatus Phytoplasma brasiliense' (16SrXV-A subgroup) associated with cauliflower displaying stunt symptoms in Brazil. Plant Disease, 97(3), 419-419.

Davis, R. E., Harrison, N. A., Zhao, Y., Wei, W., \& Dally, E. L. (2016). 'Candidatus Phytoplasma hispanicum', a novel taxon associated with Mexican periwinkle virescence disease of Catharanthus roseus. International Journal of Systematic and Evolutionary Microbiology, 66(9), 3463-3467.

Deng, S., \& Hiruki, C. (1991). Amplification of 16S rRNA genes from culturable and non-culturable mollicutes. Journal of Microbiology Methods, 14(1), 53-61.

Doi, Y. M., Teranaka, M., Yora, K., \& Asuyama, H. (1967). Mycoplasma or PLT group-like microorganisms found in the phloem elements of plants infected with mulberry dwarf, potato wishes' broom, aster yellows, or paulownia wishes' broom. Annals of the Phytopathological Society of Japan, 33(4), 259-266.

Duduk, B., Mejia, J. F., Calari, A., \& Bertaccini, A. (2008, July). Identification of $16 \operatorname{SrIX}$ group phytoplasmas infecting Colombian periwinkles and molecular characterization on several genes. IOM 17th International Congress. Tienjin, China.

Dumonceaux, T. J., Green, M., Hammond, C., Pérez, E., \& Olivier, C. (2014). Molecular diagnostic tools for detection and diferentiation of phytoplasmas based on chaperonin-60 reveal differences in host plant infection patterns. PLOS ONE, 9, e116039.

Eckstein, B., Barbosa, J. C., Rezende, J. A. M., \& Bedendo, I. P. (2011). A Sida sp. is a new host for 'Candidatus Phytoplasma brasiliense' in Brazil. Plant Disease, 95(3), 363

Fernández, F. D., Meneguzzi, N. G., Guzmán, F. A., Kirschbaum, D. S., Conci, V. C., Nome, C. F., \& Conci, L. R. (2015). Detection and identification of a novel $16 \mathrm{SrXIII}$ subgroup phytoplasma associated with strawberry red leaf disease in Argentina. International Journal of Systematic and Evolutionary Microbiology, 65(8), 2741-2747.

Fernández, F. D., Galdeano, E., Kornowski, M. V., Arneodo, J. D., \& Conci, L. R. (2016). Description of 'Candidatus Phytoplasma meliae', a phytoplasma associated with Chinaberry (Melia azedarach L.) yellowing in South America. International Journal of Systematic and Evolutionary Microbiology, 66(12), 5244-5251.

Galdeano, E., Guzmán, F. A., Fernández, F., \& Conci, L. R. (2013). Genetic diversity of 16 SrIII group phytoplasmas in Argentina. Predominance of subgroups 16SrIII-J and B and two new subgroups 16 SrIII-W and X. European Journal of Plant Pathology, 137(4), 753-764.
Gámez, R., \& León, P. (1985). Ecology and evolution of neotropical leafhopper-virus-maize association. In L. R. Nault \& J. G. Rodrígues (Eds.), The leafhoppers and planthoppers (pp. 331-350). New York, USA: Wiley.

Gundersen, D. E., Lee, I. M., Rehner, S. A., Davis, R. E., \& Kingsbury, D. T. (1994). Phylogeny of mycoplasma-like organisms (phytoplasmas): a basis for their classification. Journal of Bacteriology, 176(17), 5244-5254

Gundersen, D. E., \& Lee, I. M. (1996a). Ultrasensitive detection of phytoplasmas by nested-PCR assays using two universal primer pairs. Phytopathologia Mediterranea, 35(3), 144-151.

Gundersen, D. E., Lee, I. M., Schaff, D. A., Harrison, N. A., Chang, C. J., Davis, R. E., \& Kinsbury, D. T. (1996b). Genomic Diversity and Differentiation among Phytoplasma Strains in 16S rRNA group I (Aster Yellows and Related Phytoplasmas) and III (X-Disease and Related Phytoplasmas). International Journal of Systematic Bacteriology, 46(1), 64-75.

Hall, T. A. (1999). BioEdit: a user-friendly biological sequence alignment editor and analysis program for Windows 95/98/NT. Nucleic Acids Symposium Series, 41(41), 95-98.

Hanboonsong, Y., Choosai, C., Panyim, S., \& Damak, S. (2002). Transovarial transmission of sugarcane white leaf phytoplasma in the insect vector Matsumuratettix hiroglyphicus (Matsumura). Insect Molecular Biology, 11(1), 97-103.

Harrison, N. A., Boa, E., \& Carpio, M. L. (2003). Characterization of phytoplasmas detected in Chinaberry trees with symptoms of leaf yellowing and decline in Bolivia. Plant Pathology, 52(2), 147-157.

Hodgetts, J., Boonham, N., Mumford, R., Harrison, N., \& Dickinson, M. (2008). Phytoplasma phylogenetics based on analysis of secA and 23S rRNA gene sequences for improved resolution of candidate species of 'Candidatus Phytoplasma'. International Journal of Systematic and Evolutionary Microbiology, 58(8), 1826-1837.

Hogenhout, S. A., Oshima, K., Ammar, E. D., Kakizawa, S., Kingdom, H. N., \& Namba, S. (2008). Phytoplasmas: bacteria that manipulate plants and insects. Molecular Plant Pathology, 9(4), 403-423.

IRPCM Phytoplasma/Spiroplasma Working Team-Phytoplasma Taxonomy Group (2004). 'Candidatus Phytoplasma', a taxon for the wall-less, non-helical prokaryotes that colonize plant phloem and insects. International Journal of Systematic and Evolutionary Microbiology, 54(4), 1243-1255.

Kenyon, L., Harrison, N. A., \& Richardson, P. A. (1999). Gliricidia little leaf disease in Costa Rica. Plant Disease, 83(1), 77-77. 
Kumar, S., Stecher, G., \& Tamura, K. (2016). MEGA7: molecular evolutionary genetics analysis version 7.0 for bigger datasets. Molecular Biology and Evolution, 33(7), 1870-1874.

Lee, I. M., Davis, R. E., \& Gundersen-Rindal, D. E. (2000). Phytoplasma: phytopathogenic mollicutes. Annual Review of Microbiology, 54(1), 221-255.

Lee, I. M., Gundersen-Rindal, D. E., \& Bertaccini, A. (1998a). Phytoplasma: Ecology and genomic diversity. Phytopathology, 88(12), 1359-1366.

Lee, I. M., Gundersen-Rindal, D. E., Davis, R. E., \& Bartoszyk, I. M. (1998b). Revised classification scheme of phytoplasmas based on RFLP analyses of $16 \mathrm{~S}$ rRNA and ribosomal protein gene sequences. International Journal of Systematic Bacteriology, 48(4), 1153-1169.

Lee, I. M., Gundersen, D. E., Hammond, R. W., \& Davis, R. E. (1994). Use of Mycoplasmalike Organism (MLO) Group Specific Oligonucleotide Primers for Nested-PCR Assays to Detect Mixed-MLO Infections in a Single Host Plant. Phytopathology, 84(6), 559-566.

Lee, I. M., Gundersen-Rindal, D. E., Davis, R. E., Bottner, K. D., Marcone, C., \& Seemüller, E. (2004). 'Candidatus Phytoplasma asteris', a Novel Phytoplasma Taxon Associated with Aster Yellows and Related Diseases. International Journal of Systematic and Evolutionary Microbiology, 54(4), 1037-1048.

Maejima, K., Kenro Oshima, K., \& Namba, S. (2014). Exploring the phytoplasmas, plant pathogenic bacteria. Journal of General Plant Pathology, 80(3), 210-221.

Marcone, C., Lee, I. M., Davis, R. E., Ragozzino, A., \& Seemüller, E. (2000). Classification of aster yellowsgroup phytoplasma based on combined analyses of rRNA and tuf gene sequences. International Journal of Systematic and Evolutionary Microbiology, 50(5), 1703-1713.

Marcone, C. (2014). Molecular biology and pathogenicity of phytoplasmas. Annals of Applied Biology, 165(2), 199-221.

Melo, L., Silva, E., Flôres, D., Ventura, J., Costa, H., \& Bedendo, I. (2013). A phytoplasma representative of a new subgroup, 16SrXIII-E, associated with Papaya apical curl necrosis. European Journal of Plant Pathology, 137(3), 445-450.

Melo, L., Ventura, J. A., Costa, H., Kitajima, E. W., Ferreira, J., \& Bedendo, I. P. (2018). Delineation of a novel subgroup 16SrXIII-J phytoplasma, a 'Candidatus Phytoplasma hispanicum'-related strain, based on computer-simulated RFLP and phylogenetic analysis. International Journal of Systematic and Evolutionary Microbiology, 68(3), 962-966.
Mittelberger, C., Obkircher, L., Oettl, S., Oppedisano, T., Pedrazzoli, F., Panassiti, B., Kerschbamer, C., Anfora, G., \& Janik, K. (2017). The insect vector Cacopsylla picta vertically transmits the bacterium 'Candidatus Phytoplasma mali' to its progeny. Plant Pathology, 66(6), 1015-1021.

Miyazaki, A., Shigaki, T., Koinuma, H., Iwabuchi, N., Rauka, G. B., Kembu, A., ...Yamaji, Y. (2017). 'Candidatus Phytoplasma noviguineense', a novel taxon associated with Bogia coconut syndrome and banana wilt disease on the island of New Guinea. International Journal of Systematic and evolutionary Microbiology, 68(1), 170-175.

Montano, H. G., Bertaccini, A., Guthelle, D. K., Paltrinieri, S., \& Contaldo, N. (2015). Molecular characterisation of phytoplasmas infecting Dimorphandra spp. in Brazil. Phytopathogenic Mollicutes, 5(1), 19-20.

Montano, H. G., Contaldo, N., Pimentel, J. P., Cunha Junior, J. O., Paltrinieri, S., Bertaccini, A., \& Maini, S. (2011). Turnera ulmifolia, a new phytoplasmas host species. Bulletin of Insectology, 64(Supplement), 99-100.

Montano, H. G., Dally, E. L., Davis, R. E., Pimentel, J. P., \&. Brioso, P. (2001b). First Report of Natural Infection by 'Candidatus Phytoplasma brasiliense' in Catharanthus roseus. Plant Disease, 85(11), 1209-1209.

Montano, H. G., Davis, R. E., Dally, E. L., Hogenhout, S., Pimentel, J. P., \& Brioso, P. (2001a). 'Candidatus Phytoplasma brasiliense', a new phytoplasma taxon associated with hibiscus witches' broom disease. International Journal of Systematic and Evolutionary Microbiology, 51(3), 1109-1118.

Naderali, N., Nejat, N., Vadamalai, G., Davis, R. E., Wei, W., Harrison, N. A., ... Zhao, Y. (2017). 'Candidatus Phytoplasma wodyetiae', a new taxon associated with yellow decline disease of foxtail palm (Wodyetia bifurcata) in Malaysia. International Journal of Systematic and Evolutionary Microbiology, 67(10), 3765-3772.

Nejat, N., Vadamalai, G., Davis, R. E., Harrison, N. A., Sijam, K., Dickinson, M., ... \& Zhao, Y. (2013). 'Candidatus Phytoplasma malaysianum', a novel taxon associated with virescence and phyllody of Madagascar periwinkle (Catharanthus roseus). International Journal of Systematic and Evolutionary Microbiology, 63(2), 540-548.

Nejat, N., Valdiani, A., Cahill, D., Tan, Y., Maziah, M., \& Abiri, R. (2015). Ornamental exterior versus therapeutic interior of Madagascar periwinkle (Catharanthus roseus): The two faces of a versatile herb. A review article. The Scientific World Journal, 2015(ID 982412), 1-19.

Pardo, J. M., Truke, M. J., Cardozo, L., Varela, I., \& Alvarez, E. (2014). A real time PCR assay to detect and 
quantify $16 \mathrm{SrIII}-\mathrm{L}$ and $16 \mathrm{SrI}$ phytoplasmas associated with cassava frogskin in Costa Rica and Paraguay. Phytopathology, 105(Supplement 1), 3-3.

Pérez-López, E., Luna-Rodríguez, M., Olivier, C. Y., \& Dumonceaux, T. J. (2016a). The underestimated diversity of phytoplasmas in Latin America. International Journal of Systematic and Evolutionary Microbiology, 66(1), 492-513.

Pérez-López, E., Olivier, C. Y., Luna-Rodríguez, M., Adame-García, J., \& Dumonceaux, T. J. (2016b). Periwinkle proliferation disease associated with 16SrI-B phytoplasma in Mexico. Tropical Plant Pathology, 41(4), 254-257.

Saborío-Rodríguez, G., Villalobos, W., \& Rivera, C. (2007). First report of a phytoplasma associated with witches' broom of the giant coral tree (Erytrhina poepigiana, Fabaceae) in Costa Rica. Plant Disease, 91(11), 1512-1512.

Seemüller, E., Marcone, C., Lauer, U., Ragozzino, A., \& Göschl, M. (1998). Current status of molecular classification of the phytoplasmas. Journal of Plant Pathology 80(1), 3-26.

Šeruga, M., Škorić, D., Botti, S., Paltrinieri, S., Juretić, N., \& Bertaccini, A. F. (2003). Molecular characterization of a phytoplasma from the aster yellows (16SrI) group naturally infecting Populus nigra L.'Italica' trees in Croatia. Forest Pathology, 33(2), 113-125.

Smart, C. D., Schneider, B., Blomquist, C. L., Guerra, L. J., Harrison, N. A., Ahrens, U., ... \& Kirkpatrick, B. C. (1996). Phytoplasma-specific PCR primers based on sequence of the 16S-23S rRNA spacer region. Applied and Environmental Microbiology, 62(8), 2988-2993.

Thompson, J. D., Higgins, D. G., \& Gibson, T. J. (1994). CLUSTALW: improving the sensitivity of progressive weighting, position-specific gap penalties and weight matrix choice. Nucleic Acids Research, 22, $4673-4680$
Torres, L., Galdeano, E., Docampo, D., \& Conci, L. (2004). Characterization of an Aster yellows phytoplasma associated with Catharanthus little leaf in Argentina. Journal of Plant Pathology, 86(3), 209-214.

Villalobos, W., Martini, M., Garita, L., Muñoz, M., Osler, R., \& Moreira, L. (2011). Guazuma ulmifolia (Sterculiaceae), a new natural host of $16 \mathrm{SrXV}$ phytoplasma in Costa Rica. Tropical Plant Pathology, 36(2), $110-115$.

Villalobos, W., Moreira, L., Bottner, K. D., Lee, I. M., \& Rivera, C. (2002). First report of an Aster yellows subgroup 16SrI-B phytoplasma infecting chayote in Costa Rica. Plant Disease, 86(3), 330-330.

Villalobos, W., Montero-Astúa, M., Coto, T., Sandoval, I., \& Moreira, L. (2018). Genipa americana and Ageratina anisochroma, two new hosts of 'Candidatus Phytoplasma asteris' in Costa Rica. Australasian Plant Disease Notes, 13(1), 31.

Wei, W., Pérez-López, E., Davis, R. E., Bermudez-Diaz, L., Granda-Wong, C., Wang, J., \& Zhao, Y. (2017). 'Candidatus Phytoplasma brasiliense'-related strains associated with papaya bunchy top disease in northern Peru represent a distinct geographic lineage. Crop Protection, 92, 99-106.

Weintraub, P. G., \& Beanland, L. (2006). Insect vectors of phytoplasmas. Annual Review of Entomology, $51,91-111$.

Zhao, Y., \& Davis, R. E. (2016). Criteria for phytoplasma $16 \mathrm{Sr}$ group/subgroup delineation and the need of a platform for proper registration of new groups and subgroups. International Journal of Systematic and Evolutionary Microbiology, 66(5), 2121-2123.

Zhao, Y., Wei, W., Lee, M., Shao, J., Suo, X., \& Davis, R. E. (2009). Construction of an interactive on-line phytoplasma classification tool, $i$ PhyClassifier, and its application in analysis of the peach X-disease phytoplasma group (16SrIII). International Journal of Systematic and Evolutionary Microbiology, 59(10), $2582-2593$ 